\title{
THE IMAGE AND GLORY OF GOD IN JACOB OF SERUG'S HOMILY, «ON THAT CHARIOT THAT EZEKIEL THE PROPHET SAW»
}

\section{Fides Adorans Mysterium: The Theology of Jacob of Serug}

We do not have much reliable biographical information about Jacob of Serug. ${ }^{1}$ We know that he was born around the middle of the fifth century, the son of a parish priest in the town of Batnan of the region of Serug in the largely Syriac-speaking, Roman province of Osrhoene. He was himself ordained to the priesthood as a celibate in the early 470's, and served as circuit inspector and preacher, chorepiskopos or periodeutes, in the region of his birth. In 519, he was consecrated bishop of his native town and died there just over two years later. His works include over three hundred extant verse and prose homilies, together with several dozen letters, ${ }^{2}$ while his reputation in

${ }^{1}$ See the useful introduction by J. KollamparampIL to his translation, Jacob of Serug, Select Festal Homilies (Rome-Bangalore, 1997) 1-33, here 1-15, for Jacob's life and context.

${ }^{2}$ The Syriac texts of Jacob's homilies were published, most of them, in the following editions by Paulus BeDJAN: Acta Martyrum et Sanctorum I-VIII (Paris, 18901897); Sancti Martyrii, qui et Sahdona supersunt omnia (Paris, 1902) (note that these collections contain works by other authors as well as Jacob), and Homiliae selectae Mar Jacobi Sarugensis I-V (Paris-Leipzig, 1905-1910). Jacob's 43 surviving letters were edited by G. OLINDER, Jacobi Sarugensis: Epistulae quotquot supersunt (Paris, 1935, rep. CSCO, 110, 1965). More critical editions of selected homilies and letters, together with accompanying French translations, include the following: M. ALBERT (ed.), Homélies contre les Juifs par Jacques de Saroug // PO 38 (1976) 1-247; F. RILLIET (ed.), Jacques de Saroug: six homélies festales en prose // PO 43. 515-663; K. Alwan, Quatre homélies metriques sur la création (Lovanii, 1989) (CSCO, 508/ 509); and, in English, J. Amar, A Metrical Homily on Holy Mar Ephrem by Mar Jacob of Serug // PO 47 (1995) 1-75. M. Hansbury has recently translated a series of Jacob's homilies on Mary Theotokos: Jacob of Serug on the Mother of God (New York, 1998), with useful notes by the translator (especially in reference to Jewish traditions), and an introduction by S. BROCK. For the many other translations of single homilies into French or English which have appeared over the past century and more, several of which will also be appearing in my remarks and notes below, see the fairly comprehensive (up to 1995) listing supplied by KollAMPARAMPIL, Jacob of Serug, Select Festal Homilies... 370-379, and, up to 1986, the very thorough bibiliography 
the world of Syriac-speaking Christianity — at least of the West Syrians — is second only to St. Ephrem Syrus (†373), whom Jacob himself revered as his own model and inspiration in theology and exegesis. ${ }^{3}$

In so far as he is known at all to English speakers, Jacob is associated in a kind of troika with his two contemporaries, Philoxenus of Mabbug and Severus of Antioch, who spearheaded the resistence to Chalcedon from the 490's into the early decades of the sixth century. This association, which I think not altogether just in view of his express loathing for the sort of polemical spirit which so often informed the writings of the other two men, is assumed by the title of the one study in English exclusively devoted to all three, Roberta Chestnut Bondi's Three Monophysite Christologies, published in 1976. ${ }^{4}$ The latter's specific focus on Jacob's christology is, to the best of my limited knowledge, unique in English, though there is a more extensive literature devoted to him in French and German. ${ }^{5}$ I am very grateful to Professor Bondi's book, since it was her section on Jacob, with its abundant citations from his works, which directed me to the subject of this essay, his homily on the

by K. Alwan, Bibliographie générale raisonnée de Jacques de Saroug // ParOr 13 (1986) 313-384.

${ }^{3}$ See Amar, A Metrical Homily on Holy Mar Ephrem..., esp. the introduction, 18-21, and, at somewhat greater length on Jacob's theological debt to Ephrem, the articles by T. JANSMA, Die Christologie Jacobs von Serugh und ihre Abhängigkeit von der alexandrinischen Theologie und der Frömmigkeit Ephraems des Syrers // Mus 78 (1965) 5-65, esp. 44-45, and IDEM, Encore le Credo de Jacques de Saroug: nouvelles recherches sur l'argument concernant son orthodoxie // OrSyr 10 (1965) 75-88, 193 226, 331-370, and 475-510, esp. 349-350.

${ }^{4}$ R. Chestnut, Three Monophysite Christologies (Oxford, 1976), which, curiously, appears to have been written without reference to the very useful articles by Jansma noted just above, n.3. I might add, since I am going to be taking issue with her reading of Jacob, that I had the occasion to talk to Dr. Chestnut Bondi a few years ago and was very happy to learn that she no longer endorses the opinions in her book that I shall be criticizing. So our quarrel is, as it were, purely «academic». In view of the fact that hers is still one of the very few works on Jacob available in English, however, I do feel obliged to offer my remarks here.

${ }^{5}$ See again the bibliography supplied by Kollamparampil, Jacob of Serug, Select Festal Homilies... 383-398, though few of the entries touch directly on the christological issue, save Jansma's (above, n. 3), which I would have to reckon still the best to date. For Jacob himself on the christological controversy of his day, see J. OBEID (tr.), Deuxième epître de Jacques de Saroug sur la foi // ParOr 12 (1984-1985) 187199 (Syriac in Olinder, Jacobi Sarugensis: Epistulae quotquot supersunt... 11-16); P. KRÜGER, Le caractère monophysite de la troisième lettre de Jacques de Saroug // OrSyr 6 (1961) 301-308 (= Olinder 28-34); J.-P. P. MARTIN, Lettres aux moines du couvent Mar Bassus // Zeitschrift der deutschen morgenländishschen Gesellschaft 30 (1876) 220-275 (= Olinder 42-45, 58-86, and 241-246); and F. GrafFin, Le thème de la perle dans une lettre de Jacques de Saroug // OrSyr 12 (1967) 355-370. 
chariot (markabta) of Ezekiel, and which first signaled its echoes of the Rabbinic-era, Jewish mysticism of the merkavah. At the same time, however, I am deeply at odds with her reading of his thought, which displays what I take to be a marked dependence on the earlier - and, in important ways, superseded - scholarship of the religionsgeschichtliche Schule of such early twentieth-century luminaries as, for example, Wilhelm Bousset, Richard Reitzenstein, and Rudolph Bultmann. The presence of Oriental, chiefly Iranian motifs which these scholars believed they saw in the literature of Gnosticism and, relative to Jacob, in such early Syriac works as the Odes of Solomon and the apocryphal Acts of Thomas, ${ }^{6}$ deeply affect Bondi's analysis, since our circuit preacher makes relatively frequent allusions to passages in the Acts. $^{7}$ She thus characterizes Jacob as «overly mythological», indeed as «gnosticizing», and so finally as «rightfully worthy of rejection» by Chalcedonian and non-Chalcedonian theologians alike. ${ }^{8}$

The reality is quite different, and I think my view is supported by certain shifts in scholarship that were beginning to take place even as Bondi was writing her book, such as, for example, Robert Murray's remarkable Symbols of Church and Kingdom on early Syriac-speaking Christian literature, ${ }^{9}$ or the flood of articles and editions of texts emerging from the pen of Sebastian Brock, ${ }^{10}$ or, also during the 1970 's and extending into the 80 's, the re-evaluation of apocalyptic literature, Christian origins, and the analysis of Gnosticism which had begun to look to more proximate (as opposed to distant Iranian), Jewish sources for the reading of these ancient texts. ${ }^{11}$ We can find a

${ }^{6}$ For critique of the old history of religions school, see J. Fossum, The New Religionsgeschichtliche Schule: The Quest for a Jewish Christology // SBLSP 30 (1991) 638-646. For an example of the old school at work on Syriac Christian texts, see G. BornKam's «Introduction» to the Acts of Thomas in W. SchneEMELcher (ed.), The Apocryphal New Testament / Tr. R. McL. WiLson (Philadelphia, 1965) Vol. 2. 425442 - thus his view of «the Gnostic Christianity of Syria in the third century», p. 440.

7 See, for example, Three Monophysite Christologies... 113-118 on «Jacob's Mythological System», and 128-131 on his «Secret Jesus».

${ }^{8}$ Ibid. 141.

${ }^{9}$ R. Murray, Symbols of Church and Kingdom: A Study in Early Syriac Christianity (Cambridge, 1975).

${ }^{10} \mathrm{~S}$. BROCK's bibliography would require a modest volume. See, merely for example, the following: Mary in Syriac Tradition (London, 1977); The Holy Spirit in the Syriac Baptismal Tradition (Kottayam, 1979); The Syriac Fathers on Prayer and the Spiritual Life (Kalamazoo, 1987); Studies in Syriac Spirituality (Poona, 1988); Studies in Syriac Christianity (Hampshire, 1992); and The Luminous Eye: The Spiritual World Vision of St. Ephrem (rev. ed., Kalamazoo, 1992).

${ }^{11}$ Again, the list could be very long here. For examples, see D. S. Russell, The Method and Message of Jewish Apocalyptic (Phil, 1965); A. Segal, Two Powers in Heaven: Early Rabbinic Reports about Christianity and Gnosticism (Leiden, 1977); 
striking instance of this shift in the respective — and stunningly different analyses of the Acts of Thomas offered by Gunter Bornkam in the early 1960's for the first edition of W. Schneemelcher's anthology, The Apocryphal New Testament, and, thirty years later, by Han Drijvers for the second edition of the same anthology, where the change in direction is practically absolute. Bornkam sees nothing but «Gnosticism» and Iranian motifs in the apocryphon, while Drijers barely breathes the word, «gnostic», and does so chiefly in order to dismiss it and insist instead on the fundamentally Jewish-Christian character of the document, including the justly famous «Hymn of the Pearl», which Bornkam had seen as totally devoid of Christian elements. ${ }^{12}$

In light of this re-evaluation, much — or, in fact, all — of Jacob's «mythology» resolves into the themes of classical Christian preaching: for example, the «hiddeness of God», the angelic and earthly liturgies, the creation and fall of Adam, and the Word of God's descent into incarnation, death, and hell itself in order - using the language of the liturgy ascribed to Basil of Caesarea — «to fill all things with Himself». ${ }^{13}$ True, he confines himself

IDEM, Paul the Convert: The Apostolate and Apostasy of Saul the Pharisee (New Haven, 1990); C. Rowland, The Open Heaven: A Study of Apocalyptic in Judaism and Early Christianity (New York, 1982); J. Collins, The Apocalyptic Imagination: An Introduction to the Jewish Matrix of Christianity (New York, 1984); J. Fossum, The Name of God and the Angel of the Lord (Tübingen, 1985); IDEM, The Image of the Invisible God: Essays on the Influence of Jewish Mysticism on Early Christology (Freiburg-Göttingen, 1995); M. Himmelfarb, Ascent to Heaven in Jewish and Christian Apocalypses (New York-Oxford, 1993); J. C. ReEves, Heralds of that Good Realm: Syro-Mesopotamian Gnosis and Jewish Traditions (Leiden, 1996); and A. DEConick, Seek to See Him: Ascent and Vision Mysticism in the Gospel of Thomas (Leiden, 1996). The grandfather of this re-reading is, in good part, Gershom ScHOLEM. See thus his Major Trends in Jewish Mysticism (1941, rep. New York, 1973); and Jewish Gnosticism, Merkabah Mysticism, and the Talmudic Tradition (1960, New York, $1965^{2}$ ). For an early application, quite ahead of its time, of Scholem's insights to the study of a major figure in Eastern Christian ascetico-mystical literature, see G. QuisPel, Makarios, das Thomasevangelium, and das Lied von der Perle (Leiden, 1967). More recently on the same background in earlier Syrian Christian asceticism, see IDEM, The Study of Encratism: A Historical Survey // La Tradizione dell'Enkrateia / Ed. U. Bianchi (Rome, 1985) 35-81; together with G. G. STroumsA on a fourth-century, Syrian monastic sect: Jewish and Gnostic Traditions among the Audians // Sharing the Sacred: Religious Contacts and Conflicts in the Holy Land / Eds. G. G. Stroumsa, A. Kofsky (Jerusalem, 1998) 345-358 (my thanks to Professor Stroumsa for kindly sending me an offprint of his article).

${ }^{12}$ H. DrIJVERS, «Introduction», Acts of Thomas // New Testament Apocrypha (Phil, $1991^{2}$ ) Vol. 2. 322-337, esp. 330-333 on the «Hymn of the Pearl» — «one of the most beautiful products of Syriac literature», p. 320.

${ }^{13}$ See S. BRock's remarks on Jacob's «mythology» in Baptismal Themes in the Writings of Jacob of Serug // OCA 203 (1978) 325-347, here 325-326. 
entirely to scriptural and related language, that is, to the diction of biblical and traditional imagery, and avoids like plague the abstract terminology of Greek philosophy. One might even speak of a kind of deliberately archaizing quality to his writings. ${ }^{14}$ In any case, he detested in consequence the sort of learned, philosophical theology which he believed had done so much to prompt and sustain the christological controversy of his era - better that Nestorius had never been born, he grumbles in one letter ${ }^{15}$ - but this animus toward rational (or rationalistic) analysis of the things of God is part and parcel of his deeply traditional emphasis on a kind of «learned ignorance» or, more positively, on what he himself refers as «wonder» — worship, we would say — before the mystery of the God become man. As he puts it himself in one of his letters:

This is why the discerning soul should abandon the debate [over Christ] and be filled [instead] with the wonder of Christ. Let it be filled with the wonder Who is Christ! Whoever pries into the unsearchably Begotten [of the Father] no longer has wonder, and this is to say that he no longer has Christ in himself. If some investigation has set him off in search of wonder, this is because he has lost that wonder... Therefore, O soul, make haste rather to wonder, and take care to love. Be ready to worship. Keep yourself in a state of wonder... Open the door of your spirit to wonder. ${ }^{16}$

Robert Murray's characterization of Ephrem Syrus' theology as fides adorans mysterium holds fully for Jacob as well, which should come as no surprise in view of the latter's reverence for Ephrem as his model and guide in divinity. ${ }^{17}$

The accusation, «gnosticizing», while not true, is nonetheless perhaps more interesting, at least for me, in that it opens onto roughly the same territory that I have been poking into for the past several years and which drew me to the homily on the chariot in the first place: the origins and continuities of Christian asceticism and mysticism. The very fact that Jacob devoted a homily, and a very long one at that, to Ezekiel's chariot vision puts him at least

${ }^{14}$ See thus Jansma, Die Christologie Jacobs von Serugh... 44-45.

${ }^{15}$ Martin, Lettres aux moines du couvent de Mar Bassus... 248.

${ }^{16}$ KRÜGER, «Le caractère monophysite de la troisième lettre de Jacques de Saroug... 306-307 (= OLINDER 19, 1l. 16 ff.). On «wonder», together with love, as Jacob's keys for the approach to Scripture, see B. M. Boulos Sony, La méthode exégetique de Jacques de Saroug // ParOr 9 (1979-1980) 67-103, here 83-84.

${ }^{17}$ Murray, Symbols of Church and Kingdom... 89. For «wonder» as charged with the sense of religious transport, the Greek ekstasis, in the later writings of Isaac of Nineveh, see H. Alfeyev, The Spiritual World of Isaac the Syrian (Kalamazoo, 2000) 241-248; and cf. the richly suggestive, contemporary application of the category, «wonder», by Bishop Seraphim SigRist, Theology of Wonder (Torrance, CA, 1999). 
in rough parallel with the contemporary, Jewish mysticism of the merkabah, the divine chariot throne, and I myself think that the parallel is quite real and deliberate. Both Jacob's homily and the rabbinic-era literature of the hekhalot, the heavenly palaces - together, I might add, with many of the documents from the Nag Hammadi trove - share common roots in the much earlier, Second Temple-era literature of those Jewish apocalypses which featured an ascent to heaven and a vision of the divine throne. Both Jacob and the Jewish mystics are concerned with the contemporary possibility of experiencing Ezekiel's vision of the enthroned Glory of God, and in this they share with one of the oldest passages in apocalyptic literature, the ascent and visio gloriae of Enoch in I Enoch $14 .{ }^{18}$ Jacob, though, differs from the Jewish merkabah tradition in certain fundamental respects, most notably of course in his identification of the enthroned Glory with Christ, but also, secondly, in his assertion that the place of the Glory's abiding is the altar of the Christian Eucharist. For our preacher, heaven and earth have been joined in Christ, Who has broken down the «wall of enmity» between those above and those below. Jacob, therefore, writes precisely against the possibility or necessity of the «ascent to heaven», and I shall come back to that theme later on in this essay.

«The wall of enmity» recalls the passage on the «one new man» in Eph. 2:14-15. The latter is one of several New Testament passages which resonate throughout both this homily and, indeed, virtually all of Jacob's works that fall under Dr. Bondi's consideration, though, rather curiously, she fails to cite any one of the key scriptural loci specifically. ${ }^{19}$ These passages are, in particular, the «one mediator» of I Tim. 2:5, the hymn of Col. 1:15-20 on Christ as joining together heaven and earth, and, most especially, Phil. 2:6-7: that He who was «in the form [morphe] of God» emptied himself to take on the «form of a servant» and the «likeness [schema] of a man». The last especially, together with its obvious importance for the christological debate (Cyril of

${ }^{18}$ There is a considerable literature on I Enoch and its resonances in later apocalyptic literature. For an accessible discussion of its origins in Ezk 1 and importance for later apocalypses of ascent, see Himmelfarb, Ascent to Heaven... 9-46. The extension of this trajectory into the Syriac Christian literature of the fourth and subsequent centuries does not, regrettably, feature significantly in current scholarship. For two partial exceptions regarding Aphrahat of Persia (fl. 330's-340's), however, see J. RaAsch, The Monastic Concept of Purity of Heart and Its Sources. Part IV: The Early Monks // StMon 11.2 (1969) 280-281; and R. MurraY, Some Themes and Problems of Early Syriac Angelology // V Symposium Syriacum (Rome, 1990) 150-151. Interestingly, Murray sees Aphrahat playing in Demonstration 14.35 off of 3 Enoch, a Rabbinic-era hekhalot text.

${ }^{19}$ See, for example, Three Monophysite Christologies... 123-126 on the schema of Christ as man, though without citation of Phil 2:6-7, and the same lack of this text in her discussion of Christ in the «form of servant» in 129, or of Eph 2:15 in 135-136. 
Alexandria, for example, refers to it nearly as often as he does Jn. 1:14 ${ }^{20}$ ), is also - at least for certain contemporary scholars - itself related to the notion of the Glory of God, the kevod $Y H W H$, which features so prominently in many of the Old Testament theophanies, ${ }^{21}$ and this, too, is to be borne in mind in our consideration of Jacob's thought. Phillipians 2:6-7 is thus, thirdly, and now we move at last to the homily itself, the very center and pivot of Jacob's long meditation on Ezekiel's chariot.

\section{The Homily on the Chariot}

The homily is very long, indeed, between thirteen and fourteen hundred lines and running to over sixty pages in Paulus Bedjan's edition of Jacob's homilies. ${ }^{22}$ If length is any indication of the importance a writer accords his topic, then Jacob very clearly thought Ezekiel's vision rated quite special attention. I myself believe, although this would have to be the subject of another paper, that he is directing his words to certain among his listeners who were attracted by the idea of ascending to the heavenly throne, like Enoch in the old apocalypses, and, if one friend of mine who is more versed than I in matters Jacobean is correct in understanding his audience as primarily monks, ${ }^{23}$ then we are in fact in the presence of those ancient currents of ascetical mysticism which are of particular interest to me. As I just noted, however, Jacob sets his face against the notion of ascent, and his opposition to this tradition comprises what I would venture to call the secondary theme, or even the

${ }^{20}$ See J. McGuckin, Cyril of Alexandria: The Christological Controversy, Its History, Theology, and Texts (Leiden, 1994) Esp. the «Scriptural Index», p. 425 (twelve references, and likewise twelve for Jn 1:24). Curiously, A. GrILLMEIER restricts his discussion of Phil 2:6-7 almost exclusively to Nestorius: Christ in Christian Tradition: From the Apostolic Age to Chalcedon / Tr. J. Bowden (Atlanta, 1975²) 511 ff., save one, fleeting reference to the early Cyril in 304-305. My own impression, admittedly superficial, is that it was Nestorius who had to struggle with the text. Cyril seems to take its unity of subject for granted and deploys it accordingly.

${ }^{21}$ See M. Bochmuent, The «Form of God» (Phil 2:6): Variations on a Theme of Jewish Mysticism // JTS ns 48.1 (1997) 1-23 and, twenty years ago, the coyly allusive article by QuisPel, Ezekiel 1:26 in Jewish Mysticism and Gnosis // VC 34 (1980) 1-13. On the OT tradition of the kavod, see esp. T. D. N. Mettinger, The Dethronement of Sabaoth: Studies in the Shem and Kabod Theologies (Lund, 1982) 80-115.

${ }^{22}$ Homiliae selectae IV:543-610. In order to avoid a greater clutter of notes, I shall be including page and line numbers from Bedjan's edition in the body of my article following citations from the homily. I should also take this opportunity to declare my heartfelt gratitude to Sebastian Brock for his extraordinary kindness in offering to correct the draft of my translation. Let the reader be assured that I have incorporated every one of his corrections and suggestions - and there were a lot of them!

${ }^{23}$ I take this point from conversations with Susan Ashbrook Harvey, and hope that she does not mind my citing her here. 
subtext, of his homily. The latter's first concern, though, is to link the chariot vision with the divine economy in Christ.

With these preliminary remarks in mind, let me proceed to a sketch of the homily and then to a few concluding remarks. The whole huge piece revolves around three fundamental texts: Ezekiel 1, especially verses 26-28; Genesis 1, again particularly verses 26-27; and, as noted above, Phillipians 2:6-7. The link between all three is the Syriac term, dmuta or «likeness». In Jacob's Syriac Bible, the Peshitta, this is the single word which is used to render at once its Hebrew equivalent, demut, found in both Gen. 1:26 and Ezk. 1:26 and 28, and the morphe, «form», of Phil. 2:6-7. Jacob is the only the patristic author I know of to dwell at such length on the linkage of these three texts, though he is obviously helped by the translation he used.

\section{A. Divine Transcendence, the Imago Dei, and Macrocosm/ Microcosm}

The homily opens with what is for Jacob a typically apophatic note, stressing the mystery of God's transcendence, the «hidden One» Who is «seated on the unsearchable chariot» and is infinitely above the angels, the «assemblies of the sons of light» (543-544). ${ }^{24}$ Again typically, Jacob begs for the gift of «a new mouth» in order to offer fitting praise: «Lord most high, my mouth is insufficient for Your praise: make a new mouth for me that it may proclaim Your song» (544:18-19) ${ }^{25}$ It is at this point that the first note of the imago dei appears, that is, that it is precisely the office of the human tongue - or, indeed, as we might say, of the mind — to offer up worship. While God could have made the dumb creation sing His praises, this task has been set aside specifically for the speech-endowed image. As Jacob writes:

Let everything created abide in what is its own, as at its creation: ...the sea for fish and the earth that it may bear the sons of men... And the image with speech, that it may be stirred all the day to Your praise.

«The very pulse of my created being», he adds, «requires Your praise» $(546: 2-8){ }^{26}$

In the next section of over a hundred lines, Jacob moves in effect to a paraphrase and meditation on the opening lines of Genesis. After dwelling

${ }^{24}$ God as the «hidden», the «Hidden One», etc., appears very frequently in Jacob. On the dialectic of «hidden/revealed» in his master, Ephrem, as «between apophatic and cataphatic poles», see R. Murray, The Theory of Symbolism in St. Ephrem's Theology // ParOr 6/7 (1975-1976) 1-20, here 11, and cf. JANSMA, Die Christologie Jacobs von Serough... 38-43, on the same in Jacob.

${ }^{25}$ See Boulos Sony, La méthode exégetique... 67-68, and again 83-84 for Jacob's insistence on the need for divine grace to interpret the scriptures.

${ }^{26}$ The entire section on the speech-endowed image runs to over a page, 545:7546:11. 
again at length on God's infinitiy and unsearchability (546:12-7:18), he moves on to consider the divine power, haila, and sign, remza, which uphold and govern the universe after bringing it into being from nothing (547:18-552:2). ${ }^{27}$ God's power carries the cosmos like the force of a man's arm sustains a stone thrown into the air (552:3-3:19). This similitude allows Jacob to bring into play the ancient theme of the human being as microcosm: «The Power abides in the creation», he writes, «like a soul [abides] in its members» (553:20 and ff.). ${ }^{28}$ Here I should add that, at least on occasion, the term «power» is more than simply a way for Jacob of speaking about God ad extra. It sometimes overlaps with the Second Person of the Trinity. ${ }^{29}$ Put another way, I take him as engaging in something very like the old Logos theology of the Apologists and Alexandrines, with the Word of God acting as the divine immanence and power at work in creation, indeed, as almost a kind of world soul. ${ }^{30}$ Microcosmos and macrocosmos, or anthropos and makranthropos, reflect one another, and Jacob thus goes on to speak of the human intellect, hauna, specifically as the «image $\left[\right.$ tsalma] of the Great Being» (556:2 ff.). ${ }^{31}$ Both, the image and the original, are not confined by their respective bodies:

Heaven does not contain the Lord, although He dwells in it, Nor does the body contain the intellect, though it soujourns in it. (556:10-11)

If the body does not contain the intellect, it still seems to be the appointed place for the latter to gather itself and meet God. I venture this thought, which

${ }^{27}$ The whole section is over five pages, 547:18-552:2. On the mysterious term and concept, remza, see K. Alwan, Le 'Remzo' selon la pensée de Jacques de Saroug // ParOr 15 (1988-1989) 91-106. Alwan concludes (104) that it resembles the logos in creation, having affinities with the Stoic logos and Platonic demiurge. Curiously, he makes no mention of the Logos Christology of the Apologists as a possible influence on Jacob at the School of Edessa, whence Alwan believes Jacob takes the idea; see 95 and 104-105.

${ }^{28}$ On man as microcosm in Jacob, see B. M. Boulos Sony, L'anthropologie de Jacques de Saroug // ParOr 12 (1984-1985) 153-185, here 182-183, and at greater length, K. Alwan, L'homme le 'microcosme' selon Jacques de Saroug // ParOr 13 (1986) 57-78. For the origins of the idea in Greek philosophy, see A. MEYER, Wesen und Geschichte der Theorie von Mikro- and Makrocosmos (Bern, 1900) 1-46.

${ }^{29}$ See 544:12-14, 556:8-9, 599:13, and 603:18, where «Power» appears clearly to be taken as a name of the Son. Jacob could, of course, have had in mind I Cor 1:24 and the long subsequent play of this verse in the history of early christology. See in this regard M. R. BARnes, The Power of God: Dynamis in Gregory of Nyssa's Trinitarian Theology (Washington, DC, 2001) 94-124.

${ }^{30}$ See again Alway, Le 'Remzo' ... 100-1, if without reference to the Apologists and Alexandrians - though he does suggest the influence of the former in AlwAN, L'homme le 'microcosme'... 72 and 76-77.

${ }^{31}$ See esp. Boulos Sony, L'anthropologie de Jacques de Saroug... 171-184, esp. 175-177 on the hauna as image. 
Jacob does not elaborate on in this homily (or in any other of his works that I have read), because it is a fundamental theme in the Christian spiritual tradition to which I think he belonged, and for which there were many precedents in both Syriac and Greek Christian literature. We shall come back, briefly, to this note later on in the essay. For now, however, there is the matter of Ezekiel's markabta.

\section{B. Ezekiel and the Chariot Vision: A Great Mystery}

The fallen intellect's penchant for travelling outside the bounds in which it ought to remain — «If your intellect obeys you», Jacob writes, «confine it to the place of the body, that it may gaze within» (557:9-10) — provides our homilist with the opening for his discussion of Ezekiel's vision. In the prophet's case, the heavens were truly opened. Trembling, Jacob says, he beheld the fiery angels and

The high throne... and, glorious upon the backs Of the ministering cherubim of fire who bear it, The wondrous Glory... the Son of the Creator, Who is seated there on the high place... (558:15-19)

Let me pause here to note the clear identification of the Second Person with the divine Glory that Ezekiel sees on the chariot throne of the theophany, «in appearance as the likeness of a man» (Ezk 1:26, kmar'eh demut adam). In this instance, the Syriac word for «glory» that Jacob uses is shubha, but he deploys the more technical terms, shekinta (the Aramaic equivalent of the Rabbinic shekinah), iqara (the Aramaic term which usually renders the Hebrew kavod, «glory», in the Peshitta), and rabbuta (majesty or, more literally, «greatness») in other passages of the homily, just as we have seen him identify the Word, at least occasionally, with the haila or power. ${ }^{32}$ At this point Jacob sounds a theme that he will come back to, the secondary one or subtext I noted above. The vision of the heavenly throne and its ministering angels, he writes, which the «questing intellect» seeks is dreadful and terrible while, on the other hand, «the table of the King is full of blessing for whomever reclines at it» (559:15-16). Not for us humans, in other words, is the vision of

${ }^{32}$ For shekinta, see 569:21, 570:13, 582:11, and 602:20; for iqara, 559:13 (as an attribute of the Power, i.e., the Son), 563:2, 571:17, 576:2 (the Son made a habitation for his iqara), and 592:5 (the iqara upon the chariot); and rabbuta, 570, 19, 595:8, and 604:10. Jacob is not alone among Syrian Christians in his use of shekinta. Prior to him, see Aphrahat in Demonstrations 4.7, 18.4, and 19.4 (PS 1, ed. PARISOT, col. 152:1-2, 828:28, and 857:6-7), and nearly two centuries after our preacher, Isaac of Nineveh. For the use of shekinta in the latter, see Alfeyev, The Spiritual World of Isaac of Nineveh... 45, 165, 167-168, and 170-171. It appears therefore to have served as something of a terminus technicus for, I take it, the Second Person in Syrian Christian circles for centuries, though I know of no studies that have been devoted to this question. 
the chariot assigned the angels, but rather the altar of the Eucharist - though perhaps also suggested here is the idea that the human being is him- or herself to become a «table of blessings» for others. ${ }^{33}$

Ezekiel is then interrogated about his vision, and Jacob paraphrases the biblical passage at length, dwelling with particular gusto on the strange forms of the «living creatures», the haywata (Hebrew hayyot), who carry and accompany the throne, and who appear so prominently in some Old Testament pseudepigrapha as well as in the Jewish merkabah literature, ${ }^{34}$ together with the appearance of the Glory (here iqara) as a man seated on the sapphire throne (560:5-563:2). How then, Jacob wonders at considerable length, are we to interpret this extraordinary vision, unique in the prophetic books (563:3568:13)? Not, he insists, by «prying into that Lamp [i.e., the Son] of the Great Light». The vision, the forms which the angels take on within it, and the appearance of the Lamp and Glory as a man, properly overwhelm rational thought. Only learned fools would seek to explain it in the terms of the worldly wise. So, our preacher says, he will «not promise an explanation, but rather wonder» before the paradox of «the Word of God mounted on the cherubim» even when it is He, the Son, Who is in truth the One Who carries both them and all creation (568:14-569:17).

\section{The Mystery of the Incarnate Word Who Came to Reconcile Heaven and Earth}

Although he promises no explanation, Jacob does, of course, set out to deliver one. It comes in two parts. In part one, we start by touching on the very important - and ancient - theme of the tie between the worship of heaven and earth. Jacob begins with the worship of heaven. The chariot is explained as having been created for the sake of the angels, since otherwise

${ }^{33}$ I borrow this suggestion from one of Sebastian Brock's notes in the margins of my translation. So far as I can tell, however, Jacob does not dwell in this homily, or in any other of his works that I have read, on the interior reflection of the divine Glory. For perhaps some suggestion along these lines, see S. A. Harvey (tr.), Jacob of Serug: Homily on Simeon the Sylite // Ascetic Behavior in Greco-Roman Antiquity: A Sourcebook / Ed. V. M. Wimbush (Minneapolis, 1990) 15-28, esp. the references to the «palace» of the saint's body, p.21, and the same as «temple» on p. 23 (Syriac in BEDJAN, Acta Martyrum... 650-665, here 655 and 659). See also Boulos Sony, L'anthropologie de Jacques de Saroug... 176-177. On the theme elsewhere in Syriac-Christian literature of the human being as, in Christ, the temple and site of the heavenly liturgy and divine presence, see MurRaY, Symbols of Church and Kingdom... 262-276, together with S. BROCK, «Fire from Heaven»: From Abel's Sacrifice to the Eucharist. A Theme in Syriac Spirituality // SP 25 (1989) 229-243, esp. 239-242.

${ }^{34}$ On the appearance of the hayyot in Jewish mystical literature, see P. SCHÄFER, The Hidden and Manifest God: Some Major Themes in Early Jewish Mysticism / Tr. A. Pomeranz (Albany, 1992) Esp. 21-27, 62-64, and 129-132. 
God, Who in Himself is hidden even from them, would have given the sons of light cause for confusion and alarm. I think the passage worth quoting at some length:

And they would have been looking in all directions in order to see Him. And the assembly of the choirs on high would have been scattered by this, And the powers would have disintegrated without any order [taksis], And debates would have multiplied even there [i.e., on high], with this one saying to that one:

«Where is He? Where is the exalted One who is hidden, that we may praise Him in His place?» [cf. Ezk 3:12]

For this reason He harnessed the chariot and made the place known ....and depicted a place for his Presence/Glory [shekinta], that there it might dwell,

And He made it like a chariot, that on it He might be carried in state, That the whole vision of the heavenly ones might be concentrated, caught up, and tied

To that one place where His banner is set...

And lightning and fearful radiance issue from the chariot, to assemble the heavenly ones to great praise...

They all cry out to one another at the entry to His place. All the choirs gather and stand at the gate of the King... [and the angels] all look toward that secondary place... And are soothed by it, and shout praise before His Glory [iqara].

$(570: 6-571: 19)^{35}$

The angels would have been without means for praise had God not provided them with the «place» of the markabta, which is thus a fundamental part - I would read it as the so-to-speak sanctuary or nave — of the heavenly temple or palace (haikla, equivalent of the Hebrew hekhal). Here again, we touch on traditions that extend back into the Second Temple era. ${ }^{36}$

${ }^{35}$ For Jacob on the heavenly palace as temple, together with the chariot throne and angelic hosts, as the first of God's creative acts, see Jacob of Serug 'On the Establishment of Creation. Memra One: The First Day / Tr. R. D. Young // J. W. TRIGG (ed.), Biblical Interpretation / (Wilmington, 1988) 184-202, here 191-195 (Syriac in Homiliae selectae 3.4-27). Note esp. the phrases: «the temple of light», «the great tent [i.e., tabernacle]», and the «bridal chamber of light», all on p. 193. Note that while the «heavenly temple» is created, its «holy of holies» is not. Thus cf. below.

${ }^{36}$ On the notion of a correspondence obtaining between the heavenly and earthly temples. see, relative to the Old Testament (and Rabbinic traditions), J. D. LEvenson, Sinai and Zion: An Entry into the Jewish Bible (SF, 1985) 111-184, and, drawing on both Old and New Testaments (together with the OT Pseudepigrapha, Christian Apocrypha, Rabbinic traditions, and some patristic literature), M. BARKER, The Gate of Heaven: The History and Symbolism of the Temple in Jerusalem (London, 1991) Esp. her chapter on «The Veil», 104-132. 
Our preacher then links the worship in the «place» on high to earth when he suggests that Ezekiel was granted his vision of the heavenly liturgy because he was in exile, mourning the loss of the Temple on Zion and of its services, and grieved by the proud display of Israel's foes. Thus the vision assures him that, «even if God's ministry in the land of Judah had ceased: See! His praise thunders richly among the cherubim!» (572:9-4:6, here 573:21-22). The sight of, in effect, the most sacred furniture of the celestial temple - thus consider the likely relationship between the kapporet, «mercy seat», of the Ark and the chariot throne of the vision ${ }^{37}$ — comforts the prophet for the (temporary) loss of its terrestrial copy. Jacob will return in order to expand at greater length on this note of the linkage between the worship of heaven and earth, and of the «place» where God is to be sought and found.

For now, however, it is the prophetic vocation of the son of Buzi which draws Jacob's attention. In his understanding, all biblical prophecy touches on «the mysteries [ raze] of the Son of God» (574:10). The use of the term, «mysteries», here refers not to some esoteric doctrine of Jesus, which Dr. Bondi seems to think is the case in her section on Jacob's «secret Jesus», but rather to the divine economy accomplished in Christ. ${ }^{38}$ Mystery, raza, in this homily, as in all of Jacob's work, together with Aphrahat and Ephrem before him, is an Aramaic word taken from the lexicon of apocalyptic literature, where it signaled the secrecy of the divine counsel which is revealed to the seer, as, for example, in Daniel 2:18 ff. In the Pauline and deutero-Pauline epistles, such as most notably in Eph. 1:9 and Col. 1:26, its Greek translation, mysterion, is deployed to signal Christ, Who is God's intent or purpose for us and for all creation, the hitherto hidden goal and summation of the divine plan. This is then the sense in which it is used by the Syrian writers, who deploy it to signify the hidden meaning of the Old Testament. It is the justification for what Origen would call the «mystical» or «spiritual» sense of the Hebrew scriptures, or what we might call, simply, the christological reading. ${ }^{39}$ It is there-

${ }^{37}$ See R. ElIor, The Priestly Nature of the Mystical Heritage in Hekhalot Literature // Expérience et écritures mystiques dans les réligions du livre / Ed. P. B. FenTon, R. Goetschel (Leiden, 2000) 41-54, here 49: «...a substantial portion of the concepts mentioned in Ezekiel's consecration vision are visionary abstractions of the ritual objects of the temple mentioned in I Kings 7:23-27, 8:6-9, and II Chronicles 3:7-14, 4:3-5 and 14-15 - a visionary metamorphosis into the awesome figures of the Holy Creatures», i.e, the hayyot or cherubim. This is, of course, something of a rationalist's explanation. One could just as easily say that Ezekiel saw the heavenly originals of «the Mercy Seat». For the text and analysis of an important example of pre-Christian, Jewish traditions regarding the heavenly temple, including the «descent of the merkavah», see C. Newsom, Songs of the Sabbath Sacrifice: A Critical Edition (Atlanta, 1985).

${ }^{38}$ Three Monophysite Christologies... 128-131.

${ }^{39}$ See E. BECK, Symbolum-Mysterium bei Aphraat und Ephrem // OC 42 (1958) 19-40; and relatedly, I. H. DALmaIs, Raza et sacrament // Rituels: Mélanges offerts à 
fore through the Son of God, Jacob says, that the Father spoke to all the prophets, and it is the same Son who is Himself the content of their message: «the mystery [raza] of all the mysteries [raze] of prophecy» (574:11-16). Ezekiel's vision is no exception to this rule: it was Christ whom the prophet saw on the chariot, just as Daniel had seen Him «borne on the clouds». Here we arrive at the literal and architectural center of the homily, the point where all three texts I noted earlier converge. Quoting Jacob:

Daniel saw Him borne on the clouds [Dan 7:13], and coming

As a man to judge the kings and their empires.

Ezekiel, too, sees Him on the high throne, [He Who] was also God,

That likeness [dmuta, here obviously rendering morphe] of the servant that He assumed within the womb [of Mary]

Was whispered on the wings of the heavenly beings (575:11-16).

The manifestation of the Son and Glory of God in human form signals the paradox and promise of the Incarnation, and, in Jacob's insistence on that paradox of the one Son, we can also discern a certain echo of the Christological controversy of the era. Our preacher is nothing if not insistent on the unity of God and man in Christ, as opposed to those - dyophysites like Nestorius and his ilk — who divide and «number» the one Son. The «appearance as a man» and, simultaneously, «as God in great splendor», is «the way», he tells us, «that was trodden by the Son of God, both divinely and humanly, though He is One» (576:12-13). Turning then to interpret the fire above and below the loins of the human figure in Ezekiel's vision (Ezk 1:27), Jacob asks:

Why was it necessary for the prophet to repeat [the description of] the vision, then

To say «above» and repeat [the same] about [what is] below in his pro-

He wanted to show the higher and lower [aspects] of the Son of God, phecy? How that supernal Being had become earthly,

Pierre-Marie Guy, O.P. / Ed. P. DE Clerck, E. Palazzo (Paris, 1990) 173-182, for Jacob's predecessors, and Boulos Song, La méthode exégetique de Jacques de Saroug... 73 ff., for Jacob himself. Raza is used for both the spiritual sense of the Old Testament and for the Church's sacraments. It is well to recall that for Jacob, as indeed for Origen and others of the Greek fathers, the scriptures enjoy a real, sacramental value. The holy words carry the presence of the Word, and hence raza for Jacob, as for Aphrahat and Ephrem, can and does apply equally as a term signifying Christ's presence in the Old Testament and that same presence in the consecrated waters of Baptism, and in the consecrated bread and wine of the Eucharist. In each case, the Christian is to discern the presence of Christ beneath the «veil» of the words, or indeed of the bread and wine. Relatedly, see thus also S. BRock (tr.), Jacob of Serug on the Veil of Moses // IDEM, Studies in Syriac Spirituality... 73-89. 
And that He had become a mediator [cf. I Tim 2:5], because He stood in the midst between the [two] sides [i.e., heaven and earth]

In order to make peace [cf. Eph 2:14] between those and high and those below.

Thus He girded himself with peace in the prophecy,

For he [i.e., Ezekiel] saw something in the likeness of a [rain]bow in the clouds accompanying Him,

A sign of the peace that He would come and make with those below.

(576:18-577:4)

Here Jacob links the rainbow shown to Noah as sign of peace after the destruction of the Flood (Gen 9:11-16) with the rainbow shades of the theophany in Ezk 1:28. Both signal the peace, shaina, which the one Son wills to effect between the realms of heaven and earth, angels and human beings, and thus, more importantly, His overcoming of the estrangement between God and humanity that had resulted from the Fall:

And that strife which the serpent had started among the trees [of Eden]

He [the Son] will remove, and the quarrel will cease that had been in-

flamed.

And the hidden Father and the great Adam, who were at enmity,

Will be reconciled in the Son who stands as the mediator.

The whole Gospel of Christ, Jacob concludes, is thus depicted in the chariot vision (578:3-15).

\section{Kenosis and the Imago Dei vs. Jewish (and Christian?) Mystical Anthropomorphism}

\section{Reconciling Prophets with Apostles: the Incarnation as Explanation of the Prophecy}

The second half of the homily is devoted to the elaboration of this central point, often in fascinating and moving fashion. Space allows me only to touch on a few significant moments before moving on to Jacob's and then my own conclusions. The first is, again, another clear allusion to, and borrowing from, Phil. 2:6-7. «Look closely at Him now [on the chariot]», Jacob tells the prophet:

...Who is splendid in His great glory,

And acknowledge that this is He when He has lowered Himself to poverty...

With this type that you have been shown upon the chariot,

The land sees His humility as He delivers it.

By these faces, which He has now asked that you be shown, In them you will see Him when He has taken on a body in truth.

To this condition your Lord came down when He emptied Himself,

That the world might see Him in the form [dmuta] of a servant.

This is He who shall come in the flesh, openly [or, manifestly], 
That in Him the human race may be set free from slavery. The revelation depicted the whole path of the Son of God, And it taught Ezekiel the mystery [of the Incarnation] through that chariot.

(583:3-18)

If it were not a revelation of the Incarnation, Jacob continues, then the prophet's vision would have been simply ignored and, even, inexplicable:

Our Lord manifested Himself in the world when He came to it, And illumined the face of prophecy, with the result that everyone recognized it [i.e., prophecy, as true]...

For if God had not appeared as a man,

Ezekiel would not have been renowned for these riches,

And people would not have comprehended the scroll of his prophecy...

Yet now, because the Son of God came to the world,

Ezekiel is glorified who saw His mystery (584:3-4, 10-14).

Without the coming of Christ, the human figure on the chariot would have been cause for a genuine, theological scandal, and rightly criticized for giving shape to God who is infinite, without any limit or form:

And it would have been asked, «why did he see Him as a man

«Who, without any likeness, is glorious in the hiddeness of His high place?» "What is this, that he saw the cherubim in great splendor,

«And yet [saw] the Lord of the cherubim as a man?

«This appearance is [too] small to be about God,

«That a throne should hold Him Whose Glory even the heavens do not

contain». $(585: 2-7)^{40}$

I think that Jacob is also taking deliberate aim here at a contemporary, anthropomorphic interpretation not only of Ezekiel's vision, but of the God of the revelation, and we will see him addressing this issue quite openly in a moment. Right now, though, and with regard to the section of his homily under discussion here, I should like to underline a second reconciliation or, rather, a harmony - that he wishes to establish, and that runs through his other works as well: the agreement of the Old Testament prophecy with the New Testament preaching of the Apostles, and, with that agreement, the justice of the Church's claim to the inheritance of Israel:

...because the prophecy depicted His [Christ's] type,

The apostleship also gave the truth of His body to the world.

It is proclaimed [both] by the prophecy and the apostleship

That He Who was, is He Who is embodied...

...while those younger in the Spirit [the Apostles] declared that He had become a man,

${ }^{40} \mathrm{Cf}$. Isa 66:1 and I Kings 8:27, together with my remarks below and n.42 on the shi'ur qomah tradition. 
The elders [i.e., the prophets], too, witnessed that they had seen Him as a man.

From the testimony of prophecy and of the apostleship,

Who is it who flees, except an enemy of the faith? $(586: 21-587: 11)^{41}$

\section{A Polemical Exchange with Jewish Anthropomorphism: The Incarnate Word as the True and Original Image of God}

The phrase, «enemy of the faith», leads Jacob naturally — in his own mind, at least - to an interesting, polemical section addressed to an unnamed Jew, in which I think we catch allusions to the traditions attaching to the mystical vision of the body of God in rabbinic circles, the shi'ur qomah, or «measurement of the stature (of the divine body)», texts which are associated with the merkavah literature. ${ }^{42}$ For Jacob, the interpretation of Ezekiel's vision in accordance this latter tradition is unacceptable for several reasons. By refusing to acknowedge Christ as the meaning of the prophet's Chariot, his Jewish opponent is led first of all into absurdities. The Father's transcendent «hiddeness» is compromised and reduced to human form:

If you do not affirm that the Son of God became a man, [then] it was the hidden Father [that] Ezekiel saw on the chariot like a human being, if it was not the form of His Only [-Begotten] One...

This leads to a series of sarcastic questions about a literalist reading of the Chariot and its angels:

${ }^{41}$ See Jacob's Homélies contre les juifs, perhaps esp. Hom. 3, lines 15-118 (PO 38. 86-93) and 7, lines 201-370 (194-195). Cf. also his comparison, in our homily, of the OT and NT with the wheels of Ezekiel's chariot: «And the wheel, which is described as having been seen within the wheel, / [This is] the new Gospel within the Law which is full of mysteries. / The [one] Testament wished to reveal the [other] Testament / With the wheel and the wheel which were seen one within the other» (580:9-12). I seem to recall a similar use of Ezekiel's wheels by Maximus Confessor in the latter's Mystagogy.

${ }^{42}$ On the shic $^{c}$ ur qomah tradition in Judaism, see Scholem, Jewish Gnosticism, Merkabah Mysticism, and the Talmudic Tradition... 36-42, and M. S. CoHEN, The Shi'ur Qomah: Liturgy and Theurgy in Pre-Kabbalistic Jewish Mysticism (LathamNew York-London, 1983). Arguing for its presence in early Christianity, see J. FosSuM, Jewish-Christian Christology and Jewish Mysticism // VC 37 (1983) 260-287; and G. G. Stroumsa, Form(s) of God: Some Notes on Metatron and Christ // HTR 76.3 (1983) 269-288; and, recently, C. GIESCHEN, Angelomorphic Christology: Antecedents and Early Evidence (Leiden, 1998) Esp. $185 \mathrm{ff}$. For the lively continuation of this current in fourth- and fifth-century monastic literature, see A. Golitzin, «The Demons Suggest an Illusion of God's Glory in a Form»: Controversy over the Divine Body and Vision of Glory in Some Late Fourth-, Early Fifth-Century Monastic Literature // StMon (forthcoming). 
Well then, were the wheels joined at the axle in order to proceed, And were the wings really flying, as you are saying?

And [was] the throne the prophet saw made of stone,

And did the whole matter end [with the words] «on the throne like a man?»

(588:7-589:2)

The last question, whether the prophet's vision was all about seeing a humanlike figure on the cherubic throne, is surely directed against the merkavah tradition, for whose Jewish adepts this was in fact the point and the goal of their proposed mystical ascent to heaven. Jacob instead insists that Ezekiel's chariot was - and is - not the end of the story. First of all, I think it clear that he is aware of this Jewish tradition, and, as is arguable from elswhere in his writings, that he is to some extent in actual conversation with contemporary Jews. His seven Homilies against the Jews, for example, display a broad knowledge of traditions current among them, and in one case feature what appears to be a direct appeal to, as it were, the «Jew in the street» over the heads of the latter's rabbinic teachers:

The scribes of your people have hidden the reality from you; and your teachers have not openly spoken the truth.

Consciously or unconsciously, they have hidden the reality, and they do not show from the texts [of Scripture] the image of the Son.

Ask them!...

Say, «O, Rabbi! Show me...

O Jew! Ask these questions of your teachers.

Ask, and see what they say about Jesus!

Judaism [yehoudayuta] is full of lies! ${ }^{43}$

Perhaps there were occasional, Jewish listeners who were drawn to hear the famous preacher, or, perhaps, this is rhetorical display for an exclusively Christian audience, though the latter explanation does not entirely persuade me. The appeal I just quoted seems quite immediate. In any case, and relative to my point about anthropomorphism, Jacob is, secondly, aware of this as both an exegetical option, and — in the case of the merkavah texts — as the

${ }^{43}$ «Judaism», jehoudayuta, appears to mean the rabbinic traditions enshrined in the Mishnah and Talmud, the «Oral Torah». See Homélies contre les Juifs 7, lines 205-309 (PO 38. 156-159), together with Albert's comments on this term, Ibid. 13. While we might — and doubtless should — recoil from his ferocity nowadays, Jacob does have a certain point here. The Rabbinic exaltation of the «Oral Torah» does seem, at least in part, to have been advanced with an eye to keeping Israel distinct from those among the «nations» who laid claim to the written Torah, i.e., the text of the OT, and then who said that they were true Israel. This certainly sounds like Christians. Thus see, for example, the sources quoted and discussed recently by H. K. HARRINGTON, Holiness: Rabbinic Judaism and the Graeco-Roman World (London-New York, 2001) 139-142. 
stated goal of mystical experience. At a couple of points in our homily he himself plays on the shi'ur qomah tradition, as in the lines: «Ezekiel saw the likeness [dmuta] on the chariot/ As a man $[a(i) k$ bar nasha] higher than the summit of the heavens» (591:19-20). ${ }^{44}$ The most striking instance and demonstration of his familiarity with the idea of the vast dimensions of the divine body, however, occurs in his prose homily on the Epiphany. Here he presents John the Baptist as having come to announce that «the Great Body [gushma rabba] has arrived to make itself visible», and to «infuse earnestly into her ears [i.e., of the Church as bride] the grandeur of the Lord [rabbuta d-marya] as well as his own [i.e., John's] smallness». Jacob concludes the relevant section of this homily with the following:

...he [the Baptist] wanted to show the bride the loftiness of the stature [rawma d-qawmta] of the Bridegroom while instructing her, and said, «The sandals of your Betrothed are exalted above my head. As I extend my hands, I am not able to reach their laces... the beauty of His stature [shuphra $d$-qawmteh] is well above my head... as the height is above the abyss, as heaven above the earth. ${ }^{45}$

The repetition here, which I take to be deliberate, of qawmta, the precise Syriac equivalent of the Hebrew qomah, is itself striking, and moreso the accompanying image of Christ's enormous size, with the Baptist shorter than the arch of the Lord's foot, a point which the former then underlines by declaring that the difference between their respective sizes is more absolute than even that startling comparison: Christ's hugeness is to John's littleness «as the height is above the abyss, as heaven is above the earth» (cf., perhaps, Isa 66:1?). Perhaps most telling of all is the setting of these passages within the language of bride and bridegroom, which I would read as at least a partial and, again, deliberate echo of the Song of Songs. If so, this would underline Jacob's conscious play on the Jewish literature of the shicur qomah, since the latter tradition specifically linked the mystical vision of the divine body with the bride's enraptured description of the limbs of her beloved in Song of Songs 5:10-16. ${ }^{46}$

${ }^{44} \mathrm{Cf}$. my discussion below, and, for examples of an ancient Christian description of the height of the risen Christ as «overpassing the heavens», see the Gospel of Peter 10.40, in SchneEMELCHER, New Testament Apocrypha... Vol. 1. 225, and cf. a similar passage regarding Christ at the Transfiguration in the apocryphal Acts of John 90; Ibid. Vol. 2. 180-181, together with Fossum's analysis of the latter in the light of Ex 33 and the shi'ur qomah tradition: Partes Posteriori Dei: The Transfiguration of Jesus in the Acts of John // IDEM, The Image of the Invisible God... 95-108.

${ }^{45}$ Kollamparampil, Jacob of Serug, Select Festal Homilies...7, pp. 192-193. For the critical edition of the Syriac text, see RiLliet, Six homélies festales en prose // PO 43. 552, line 32; and 553, lines 13 and 16-21.

${ }^{46}$ See Cohen, The Shic ur Qomah: Liturgy and Theurgy... 99-123 on «the divine limbs», and note his suggested dating (51-70) of the present text entitled Shicur qomah to the sixth century, which is to say, perhaps roughly contemporary with Jacob. 
But if Jacob knows about these traditions, and is not above playing with them, he still insists on reading the appearance of the human form in Ezekiel's vision as a prophecy of the Son who is coming to be born of the Virgin:

[It is] for this that the chariot came down to the earth,

That through prophecy it might represent the descent of its Lord.

And the glorious throne and blue of chastity that [Ezekiel] saw there

[Is] the womb of Mary, which He [the Lord] kept closed in order to bear the Son of God.

Also, that likeness which was seen upon the throne

[Is] the Son of God who came in the flesh as a man. (589:15-18)

It is of some note, I think, that the blue of the prophet's sapphire throne, which is itself surely an echo of the blue of the pavement beneath the divine throne in the theophany of Ex 24:10, denotes Mary Theotokos. This might suggest the reason for the traditional color - blue - most often associated with her in Christian iconography. Certainly Jacob is himself quite clear that the whole «throne and seat upon the chariot...[is] an image of the Virgin Mother» (590:6-7), ${ }^{47}$ and we might in our turn recall that «throne» and «chariot» (and even «mountain» — recalling the theophany at Sinai?) are, both of them, images of the Theotokos regularly deployed in Orthodox hymnography. ${ }^{48}$

It is this insistence on God incarnate which is the key to Jacob's argument with the Jew, and therewith to his adjustment of the merkabah and $s h i^{c} u r$ qomah traditions. The divine body is certainly a reality, but it is the body of the Word made flesh, who is also, however, and precisely as incarnate, the prototype of Adam. Here we arrive at Jacob's subsequent reiteration of the theme of the imago dei. All the wonders of Ezekiel's chariot throne, he writes, including the fiery spirits in their strange and terrible forms, the «fire of burning» and the wheels of flame, the crystal and the sapphire, all the heavenly assemblies, are dominated by a human form. The Lord of the angels, Jacob points out, was seen by Ezekiel «as a man». Here, in lines which recall Irenaeus of Lyons centuries earlier, we find Jacob's statement that Adam was created in the likeness of the incarnate Word:

${ }^{47}$ Cf. Hansbury, Jacob of Serug on the Mother of God... 19-20 (the Theotokos as «chariot» and «palace»); 53-55 (as the «Ark» worshipped by Zechariah in the Temple and like the darkness of Sinai's cloud); 59-60 (again like the chariot and the cloud at Sinai); 74 (the Baptist dances in Elizabeth's womb like David before the Ark); and 80 (the Theotokos as greater than the chariot).

${ }^{48}$ The Akathistos Hymn is especially rich in this imagery. Likewise rich are, of course, the Marian feasts in the Menaion. See, for example, the theotokion following the exapostolarion of the matins for the Annunciation: «Hail Theotokos... holy Mother of God... living Bush [i.e., Ex 3]... lamp... throne... ladder and gate... divine chariot... swift cloud... temple... vessel of gold... mountain... tabernacle and temple...»; The Festal Menaion / Tr. Mother MARY, K. WARE (London, 1977) 459. Virtually all of Jacob's imagery is here. 
Before creation the Father had drawn the image [tsalma] of His Son,

And depicted Him, and showed Him how He would shine forth on all the earth.

The Father gazed at the likeness [dmuta] of His Son, and molded Adam.

Since He was going to give [the Son] to the world, He delineated Him beforehand.

For this cause He said, «Let Us make man in Our image [tsalma, Gen $1: 26] »$,

In this same likeness [dmuta] in which Mary gave birth to the Only

The Father willed to send Him into the world as a man,

[-Begotten]One.

And drew beforehand His form [tsurta], the Great Image [tsalma rabba], in Adam.

Ezekiel saw the likeness [dmuta] on the chariot

Like a human being, [seated] above the backs of the heavenly beings. $(591: 11-20)^{49}$

Here again we should note the play of the three central texts which I pointed to earlier as the core of the homily: Gen 1:26-27, Ezk 1:26-28, and Phil 2: 6-7, with the first two finding their explanation and coherence in the third, the proclamation of the self-emptying and Incarnation of the Son.

\section{Visio dei: The Glory and the Image - Polemic against an Archaic Christian Mysticism?}

I might add that, in view of what we saw above concerning the microcosmos and macrocosmos, anthropos and makranthropos, it makes a kind of humorous sense for Jacob to have remarked earlier on that the «Word sits on the throne [before Ezekiel] in order to get accustomed /To human dimensions» (577:17-18). While he is obviously toying in a playful way with the shi'ur qomah traditions, it is also true that the imagery of the Power as makranthropos, i.e., of the Word investing the cosmos like the soul in a human body, «downsizing», as it were, in order to be incarnate is both ancient and frequent, particularly among Syriac-speaking Christians. We find it, for example, in the Odes of Solomon, in Aphrahat and Ephrem, and in the Syrianinfluenced Macarian Homilies. ${ }^{50}$ It might well comprise the original force of

${ }^{49}$ Cf. B. M. Boulos Sony (tr.), Hymne sur la création de l'homme de l'Hexaemeron de Jacques de Saroug // ParOr 11 (1983) 167-200 (Syriac in Homiliae selectae 3.10229), esp. 179-182 (Syriac 110-112) on the creation of Adam as a prefiguration of the Incarnate Word - and note Jacob's play on Gen 1:26, 2:7, and Phil 2:6 ff. in 179180 (110). For Irenaeus, see Irenaeus of Lyons, On the Apostolic Preaching 11 / Tr. J. BEHR (New York, 1997) 46-47.

${ }^{50} \mathrm{See}$, for example, the Odes of Solomon 7.3: «For in his kindness he has made his greatness small»; ed. and tr. J. H. Charlesworth (Chico, 1977) 35 (Syriac 33) though note that I have been obliged to alter the translation as Charlesworth misses the 
the kenosis passage of Phil 2:6-7 itself. ${ }^{51}$ To be sure, Jacob, as a faithful not to say emphatic - adherent of the Creed of Nicea-Constantinople and the homoousion, is obliged to understand the notion of «the Great One making himself small» in a metaphorical sense, not a literal one, but he is still just as clearly drawing on very old traditions of the imago dei in its relation to the divine Glory, the kevod YHWH..$^{52}$ Then, too, the notion that the Second Person particularly, as in the old Logos christology, is already in a sense vested with a body, that is, with the cosmos itself, lends extra force to the imagery here.

With regard to a «mythological», that is, literal reading of the divine body, I must add that I am not so sure that Jacob's debate is exclusively with Jewish exegesis and mysticism. I think, rather, that his remarks were also (or even primarily?) directed to some among his Christian audience who may well have been tempted by - or, more accurately, who had never abandoned and continued to affirm — an anthropomorphic understanding of the divine form, as well as a mysticism of ascent similar to the merkavah lore..$^{53}$ Criticism of anthropomorphism, perhaps especially in an ascetico-mystical context, together with the insistence on an interiorized reading of the ascent to heaven motif from apocalyptic literature, run together like a kind of crimson thread from the second and third centuries in Clement and Origen of Alexandria,

point, rendering rabbuta with «dreadfulness». See on this verse, and in contrast, Stroumsa, Form(s) of God... 283-284. In Aphrahat the play between «greatness» and «smallness» in reference to Christ's economy (and so to Phil 2:6 ff.) occurs frequently, e.g., in Demonstration 23.59, PS II, 121:9-14. Cf. also Ephrem, Hymns on the Nativity 4.186-188 // Ephrem the Syrian, Hymns / Tr. K. McVeY (New York, 1989) 102; and Macarius, The Fifty Spiritual Homilies 4.9-12 / Tr. G. Maloney (New York, 1992) 54-55; crit. ed. by H. DörRies, R. Klosterman, M. Kroeger (Berlin, 1964) 33-37. The latter is also discussed by Stroumsa, Form(s) of God...

${ }^{51}$ See again Stroumsa, Form(s) of God... 283; together with Quispel, Ezekiel 1:26 in Jewish Mysticism and Gnosis... 8-9; Fossum, Jewish-Christian Christology... 268-269; Segal, Paul the Convert... 59-62; IDEM, Paul's 'Soma Pneumatikon' and the Worship of Jesus // The Jewish Roots of Christological Monotheism / Ed. C. C. Newman (Leiden, 1999) 258-276, esp. 263; and Bockmuehl, The «Form of God»... 11-19.

${ }^{52}$ On the relationship between Gen 1:26-7 and the kavod of the OT theophanies, see J. BARR, Theophany and Anthropomorphism in the Old Testament // VT Suppl. 7 (Leiden, 1960) 31-38; and on the same linkage in the Rabbis, A. Goshen-GotTstein, The Body as Image of God in Rabbinic Literature // HTR 87.2 (1994) 171-195.

${ }^{53} \mathrm{My}$ friend and colleague at Marquette, M. R. Barnes, has recently suggested to me that Apollinaris' christology might have featured similar assumptions about the divine body of the Word, and pointed me to Gregory Nyssa's Against Apollinarius, taking issue esp. with the idea of a pre-existent «divine man» and «heavenly flesh». I look forward to Dr. Barnes' essay on this issue. 
through such fourth-century, monastic writers as Evagrius Ponticus and the Macarian Homilist, and all the way to the fourteenth-century, Byzantine Hesychasts. I have touched on this polemical current in other articles, ${ }^{54}$ so I shall not dwell on it here, save to note, first, that I find it impossible to believe that all this smoke does not point to some kind of fire. Second, we have only to glance at a couple of Jacob's immediate neighbors and contemporaries around the turn of the sixth century to see that he was not alone in his concerns. The Syrian mystic, Stephen bar Sudaili, presents us with a kind of curious, Christian variant of rabbinic-era, hekhalot mysticism, while the much better known body of writings, written under the name of Dionysius the Areopagite, directly addresses the issues of both anthropomorphism and of ascent. Let it suffice me here to quote some phrases from the fourth chapter of Dionysius' famous little treatise, The Mystical Theology:

The Cause of all... has neither a body [soma], nor shape [schema], nor form [eidos]... neither is He a place [topos], nor seen... nor perceived [by the senses]... nor is He troubled by material passions... nor is He in need of light... nor does He have, nor is He any of the things which are perceived by the senses. ${ }^{55}$

All four of the Greek terms that I have highlighted are at issue, given their Syriac equivalents (respectively: gushma, eskhema, dmutaltsurta, and atra), in Jacob's homily. All four (or five) — body, form, likeness/shape, and place are also arguably important from the time of the Second Temple apocalypses, and they are decidedly so in the hekhalot and shi'ur qomah texts. The association of God with light, also highlighted in my text from Dionysius, is like-

${ }^{54}$ See, e.g., Golitzin, «The Demons Suggest an Illusion of God's Glory in a Form»...; A. Golitzin, Temple and Throne of the Divine Glory: 'Pseudo'-Macarius and Purity of Heart // Purity of Heart in Early Ascetic and Monastic Literarture / Ed. H. A. Luckman, L. Kulzer (Collegeville, 1999) 107-129; and, specifically to the matter of the shift from an exterior to an interior appropriation of the Glory in Eastern Christian ascetical literature, A. OrLov, A. Golitzin, «Many Lamps are Lightened by the One»: Paradigms of the Transformational Vision in the Macarian Homilies // VC 55 (2001) 281-299.

${ }^{55}$ Mystical Theology 4 // PG 3. 1040D; crit. text: Corpus Dionysiacum II / Ed. G. Heil, A. M. RitTer (Berlin-New York, 1991) 148. For Stephen bar Sudaili, see F. S. Marsh, The Book which is called The Book of the Holy Hierotheos (London, 1927). On Stephen as advocating a form of pantheistic, though still ostensibly Christian hekhalot mysticism, see R. A. ARTHUR, A New Interpretation of the Context and Purpose of the Pseudo-Dionysian Corpus. (Unpub. D. Phil. dissertation, Kings College, University of London, 1998) 36-39, 54-79, and esp. 131-146. For Dionysius as replying to relatedly controverted issues involving the understanding of mysticism and liturgy among Christian ascetics, see A. Golitzin, Dionysius Areopagita: A Christian Mysticism? // Pro Ecclesia (forthcoming). 
wise fundamental to the earliest biblical theophanies, and it carries right on being so in subsequent Jewish and Christian mystical writings. ${ }^{56}$ So far as Jacob is concerned, however, the merkavah is not the last word in divinity. Rather, he insists to his listeners that it is of little or no consequence. God transcends the chariot which, as we saw above, is merely an act of divine condescension for the needs of the angels, the sanctuary of their (created) heavenly temple. But, as for the godhead itself, that «citadel of light» which is the «place» and being of the triune mystery, the «holy of holies» of the divine essence:

There is no chariot there, either to ascend to, or to seek out,

Nor are there wheels, nor creatures in their [different] kinds

Where the Trinity dwells in great splendor. $(601: 1-3)^{57}$

Secondly, and specifically in reference to the matter of light and fire, Jacob recalls Dionysius' more famous apophaticism:

The place is empty, for it is filled with divinity...

And had [angelic]fire ascended to it, [that fire] would have been burnt up by His Breath...

It is not for the spirits or luminaries to be surrounded by Him, And neither radiance nor honor enters to live with Him.

Nor does the glory of anything created come nigh Him.

The place is sublime...

The Trinity transcends the word of everything that speaks,

The divinity is in a place far from all inquirers,

${ }^{56}$ On light/fire in Jewish mysticism, see I. CHERnus, Visions of God in Merkabah Mysticism // JSJ 13.1-2 (1982) 123-146; IDEM, Mysticism in Rabbinic Judaism: Studies in the History of Midrash (Berlin-New York, 1982) Esp. 74-87 on «the splendor of the Shekinah»; C. R. A. Morray-Jones, Transformational Mysticism in the Apocalyptic-Merkavah Tradition // JJS 43 (1992) 1-31; Goshen-GotTsteIn, The Body as Image of God... 178-183; W. F. SMELIK, On the Mystical Transformation of the Righteous into Light // JSJ 27.2 (1995) 122-144, esp. 131-143. For a still useful selection of light passages from Eastern Christian monastic literature, though totally without sensitivity to their Jewish resonances (identifying them rather as «Neoplatonist» in origin), see H. V. BEYER, Die Lichtlehre der Mönche des vierzehnten und des vierten Jahrhunderts, erörtet am Beispiel des Gregorios Sinaïtes, des Evagrios Pontikos, and des Ps-Makarios/Symeon // JÖB 31.1 (1980) 169-196.

${ }^{57}$ See also Jacob's homily, «On the Ascension», in Kollamparampil, Jacob of Serug, Select Festal Homilies...348-352, especially Christ's ascent above all the angelic orders to «the exalted place» $(348$, line 380$)$, the «holy of holies» $(349$, lines 409-410), «the tabernacle of the Father» (350, lines 433-434), and «the hidden place» (351, line 445). For the related expressions: «the brightness of the godhead», «the citadel of the light of his being», and «that place [haw atra]», see his homily «On the Establishment of Creation»; TRIGG, Biblical Interpretation... 187. 
The Father begetting and the Son begotten and the living Spirit:

The Being Whose place no one knows, save He alone. (601:9-602:5) s8 $^{58}$

Thus, a few pages later, we find an express prohibition directed against a mysticism of ascent to the divine chariot: «O Sinner! In your seeking, do not look for Him on high!» (606:3). The prohibition against making a heavenly journey suggests to me that some of Jacob's audience were interested in doing just that.

\section{E. The «Place» of our Encounter with God: the Altar of the Church}

A last highlight, before we move to my concluding remarks, concerns the «place» where Christians ought to be looking to encounter the splendor of divinity. This is, again, Jacob's subtext, and as well a reprise of the theme of a linkage between heavenly and earthly liturgies, of the mutual reflection of the celestial and terrestrial temples, that we saw him sketch in his initial explanation of the prophet's vision. In a wonderful passage, he takes up Ezk. 10 , with its image of the «angel in white linen» approaching the chariot in order to receive coals of fire from the hand beneath the throne, which the angel then scatters over Jerusalem as a sign of the judgement ordained for the city. This picture, Jacob tells us, is a type of the Eucharist (and note the reference he works in to the temple vision in Isaiah 6:1-6):

The Son of God is all the beauty of prophecy,

And without Him there is neither prophecy nor revelation.

In the coals of fire are depicted the pearls of His body,

And in the chariot [is a portrait of] the holy altar of divinity...

These coals of fire that are in the chariot depict His body.

They were placed in it both for retribution and for forgiveness.

${ }^{58}$ On the significance of the term, «place», in the scriptures as denoting the locus $d e i$, and specifically associated generally with theophany and with the tabernacle/ temple in particular, see the articles by H. RingGREN, maqom // TDOT. Vol. 8. 532548; and H. KösTER, topos // TDNT. Vol. 8. 187-208. On the deployment in Rabbinic thought of maqom as divine name, denoting God's omnipresence and on occasion overlapping with shekinah, see E. E. URBACH, The Sages: Their Concepts and their Beliefs / Tr. I. Abrahams (Cambridge, MA, 1995) 66-79. For its importance in the Gospel of Thomas as a virtual synonym for Christ and the divine light, see DeConICK, Seek to See Him... 65-73, esp. 70-71, and relatedly 99-122. See also C. STEwart, Imageless Prayer and the Theological Vision of Evagrius Ponticus // JECS 9.2 (2001) 173-204, for a sensitive exploration of the meaning of topos in Evagrius' mystical theology, though Steward does not touch on the wider and older resonances of the word save for noting some of the key scriptural loci. That Evagrius was aware of these wider reverberations, however, including their echoes of temple traditions, seems clear from the short but very valuable article by N. SÉD, «La shekinta et ses amis araméans // COr 20 (1988) 233-242. The topic merits an extended study. 
One [of them] was given to Isaiah, to forgive his iniquity,

And [others] were scattered in Jerusalem for punishment.

The liturgy of heaven and the worship of the Church are therefore one and the same:

Within the Chariot [were] holy coals of fire,

In the holy altar [are] precious pearls.

On the altar is the body, and on the chariot fire abides,

Since both above [in heaven] and below [on earth] there is a single mystery [or, perhaps, sacrament] of the Only [-Begotten] One. $(596: 2-14)^{59}$

The angel himself is «a type of the [Christian] priest clothed with the form [tsurta] of the Son of God», while the hand beneath the chariot is an image of the Holy Spirit. It is the Latter Who is the agent of the Eucharistic change, as Jacob makes clear in an extended passage on the meaning of the consecratory epiklesis:

It is not the [human] priest who has authority to sacrifice the Only [-Begotten] One,

And to lift Him up before His Father as a sacrifice for sinners.

Rather, the Holy Spirit comes forth from the Father,

And descending, He overshadows [shra] and dwells [shken] within the bread, and makes it the Body...

And the Spirit Who is within stretches out to the priest who is outside,

Like the cherub stretched out to the man who was in white linen,

And [the priest] takes from Him the propitiatory fire in the hollow of his hand,

And, taking it out, he gives flowing wealth to all the world. (597:5-18) ${ }^{60}$

At this point, Jacob moves on to link together the worship of both the Old and the New Covenants with that of heaven. He rightly notes the expressly sacerdotal imagery of Ezekiel's angel in white linen:

The priests of the People [i.e., Israel] were clothed in [white] linen within the Holy of Holies [cf. Lev 16:2-14, the liturgy of Yom Kippur],

Just as the angel at the chariot was clothed in [white] linen.

It was not the angel who took his cue from the priest who was clothed,

But rather [it was] the priest who was made like that angel.

${ }^{59}$ On «Fire» as one of Jacob's favorite words for the Word, see BROCK, Baptismal Themes... 334-336. «Fire» is likewise one of the Rabbis' favorite expressions for the word of revelation, so cf. HARRINGTON, Holiness... 132-133 and 155-156.

${ }^{60}$ Recall Jacob's use of shekinta as denoting the Second Person (above, n.32), and note here his use of the same root, $s k n$, in verbal form, for the action of the Spirit at the Eucharistic epiklesis. Thus the Spirit's coming to dwell (shken) in the Gifts makes present the dwelling (shekinta) among us of Christ, the Immanuel. 
Which is to say, that the Old Covenant Tabernacle and Temple were also an image of heaven. Thus Jacob continues with a reference to Exodus 25:9 ff., that is, to God's revelation on Sinai of the heavenly «pattern» (in Hebrew, tabnit, and in the Peshitta — again! — dmuta) of worship:

Moses saw the whole form [tsurta] of these mysteries,

And he came down [from Sinai] to trace it in the tabernacle and its fur-

And, just as Moses saw, so Ezekiel saw [them] as well... nishings.

The mystery of the Church was prior to both Moses and Ezekiel,

And on it the angels, too, longed to gaze. (598:18-599:8)

Our preacher depends here on a tradition that was already old by the time of Christ, which is that, at the time of the revelation on Sinai, Moses was accorded a vision of - or, in some accounts, an actual ascent to - heaven where he was shown the celestial temple and liturgy. ${ }^{61}$ Likewise, the reference here to the Church as antedating both Ezekiel and Moses is, first of all, dependent on another, related tradition: that Paradise was designed as a temple, and that Adam's original calling was to be priest. We find the idea implicitly in the accounts of the Hebrew scriptures themselves in the relationship obtaining between Genesis, Exodus (on the making of the tabernacle), and I Kings (the design and consecration of Solomon's temple). The idea then becomes explicit as early as Jubilees in the second century B.C., and it is quite prominent in Jacob's own beloved Ephrem, particularly in the latter's Hymns on Paradise. ${ }^{62}$ As Jacob himself puts it in another homily:

God made the gift of priesthood to men

In order that they might be consecrated by means of it.

In His love for peace [shaina], He bestowed this gift on them

${ }^{61}$ On Moses' ascent to heaven, see the materials assembled by W. A. MeEKs in the latter's The Prophet King: Moses Traditions and Johannine Christology (Leiden, 1967) 122-125 (Philo), 140-142 (Josephus), 156-159 (the OT Pseudepigrapha), 205211 (Rabbinic midrash), and 241-246 (Samaritan traditions).

${ }^{62}$ On the linkage between the Temple and the creation stories of Gen 1-2 (including Eden), see M. Weinbaum, Sabbath, Temple, and the Enthronement of the Lord: The Problem of the Sitz im Leben of Genesis 1:1-2:3 // Mélanges bibliques et orientaux en l'honneur de M. Henri Cazelles / Ed. A. Caquot, M. Delcor (NeukirchenVluyn, 1981) 501-512; LeVEnson, Sinai and Zion... 111-184; and esp. BARKER, The Gate of Heaven..., particularly her chapter on «The Garden», 57-103. For Ephrem (also cited at the close of Barker's chapter), see St Ephrem of Syria, Hymns on Paradise / Trans. S. Brock (New York, 1990) Esp. 3.7-16 and 14.7-12, pp. 93-96 and 184-186. Syriac text in Sancti Ephraem Syri in Genesim et in Exodum Commentarii / Ed. R.-M. Tonneau (CSCO, 174) 10-12 and 60-61. See also Brock's helpful sketch of the traditions Ephrem is working with in the former's «Introduction», Hymns on Paradise, esp. 49-74. 
And exalted them, so that they might offer Him their sacrifices.

In order to mingle them with Himself in His glory [shubha] and majesty

[rabbuta],

He established them in His spiritual ministry [teshmeshta]. ${ }^{63}$

The imagery of «mingling» is typical of Syriac-speaking Christians from the earliest texts we have in that language, and here it obviously denotes what the Greek Fathers refer to as deification, theosis, the gift of participation in God's uncreated glory. Adam did not fulfill this vocation. He did not make «peace», shaina, but Christ, as we have seen Jacob emphasize, did: «This deed our Lord came down and accomplished on the earth». ${ }^{64}$ Paradise, Sinai and Temple, heaven and the Church's worship, are all of them joined in Christ, who thus is the bond between both the beginning and the end, and between those on high and those below. I think it also worth noting that we find several of the terms I have dwelt on, particularly in the preceding section on mystical ascent and anthropomorphism, repeated here in reference to the liturgy of heaven and earth: body, form, likeness, and place. This is not accidental. The true «body of God» is here, on the altar. The «form of God» - i.e., the incarnate Word — is depicted in the celebrating priest; who reveals, together with the rest of us in solemn assembly, the «likeness» of heaven, and so the «place» of the divine rest. ${ }^{65}$

Thus we arrive at the force of Jacob's concluding remarks. He follows his prohibition against heavenly ascent, which I cited at the close of the last section, with the following affirmation:

${ }^{63}$ M. Albert, Mimro inédit de Jacques de Saroug sur le sacerdoce et l'autel // ParOr 10 (1981/2) 51-77; here 55, lines 2-6. I am translating quite unashamedly from Albert's French, with one exception. In line 5, she renders the Syriac $d$-nhlwt ' $n w n$ bh with «Afin de se les associer». I have changed her «to associate» into the more literal «to mingle». On «mingling» as a key term in Syriac Christian discourse, particularly as conveying the sense of the Greek theosis, see C. STEWART, «Working the Earth of the Heart»: The Messalian Controversy in History, Texts, and Language to A.D. 431 (Oxford-New York, 1991) 171-203; and, more briefly, on the same language in Isaac of Nineveh, cf. also AlfEYEv, The Spiritual World of Isaac of Nineveh... 56-58.

${ }^{64}$ On Christ's priesthood elsewhere in Jacob, see again the passages from his homily «On the Ascension» cited above, n. 57, where Christ's ascent is presented as the triumphal entry of the High Priest into the Holy of Holies. Cf. also the AlberT, Mimro inédit sur le sacerdoce... 59-64, together with J. THEKEPARAMPIL (tr.), Jacob of Serug's Homily on Malkizedeq // The Harp 6.1 (1993) 53-64, esp. 55 ff.

${ }^{65} \mathrm{I}$ would read this as very similar - even identical in intent (if not in its lexicon) — to Dionysius Areopagites' opening lines in Celestial Hierarchy 1.3 (121C124A; HeIL, RITTER 8:14-9:15) on the liturgy of heaven as mirrored in that of earth, together with his definition of hierarchy in 3.1-2 (164D-165A; HeIL, RitTER 17:10 18:6) as intended to shape its members, both collectively and severally, into «the form of God» (to theoeides). 
He has come to you, to your place. Look at Him! for He is with you

At the altar as [at] a meeting-place with you, so that you may see Him as

He rests upon the table,

And from the particles of His body all creation is satisfied. (606:4-7)

This is why we are not to go looking for a way to climb up to heaven, nor be jealous of the angels' service of the merkavah. If anything, Jacob suggests, they should jealous of us! The Presence, the shekinah, is right here:

All the wealth of the heavenly beings has descended to the earth

In Immanuel, Who is [both] with us, and is our God.

The hidden altar, which is ministered to in mystery -

Look! [It] is revealed, and is [lit. «stands»] among earthly angels [i.e, us]...

Look! in the ministry of the holy altar, at the time of the Mysteries,

Are marshalled the [heavenly] powers, standing with their cries of «Holy».

We lack nothing that the angels have. «If», Jacob adds, «the eye of our soul were as limpid as the prophet's», we would be able see «the shining throng of their hovering» (607:13-608:3). Indeed:

All the mysteries that were hidden among the angels

Come to pass in her [i.e., the Church], and it is she who is the schoolmistress of the heavenly beings. (609:7-8)

There is therefore a greater thing among us now than Ezekiel's chariot throne. If in heaven the cherubim «bear Him upon their backs with wonder», in the Church on earth we may «hold Him fast in the hollows» of our hands (609:13-14).

\section{Some Concluding Thoughts and Observations: A Call to Biblical Theology?}

There is more that I could say, including the lovely symmetry of the piece, beginning as it does with the «Exalted One on the unsearchable chariot», and concluding with the mystery of «the Crucified One in whom all the mysteries are accomplished», in which juxtaposition we might discern an echo of I Cor 2:8; or Jacob's remarks on the «Virgin Church», backed by the wealth of an ecclesial imagery with profound roots in the scriptures and tradition; or the matter of his intriguing allusions to the «inner place» where the Christian intellect is to fasten its attentions, phrases at the least suggestive of a spiritual tradition that we meet in Aphrahat, the Liber Graduum, and the Macarian Homilies — but all these riches must await another day. There is enough in what I have said, I think, for me to say now that his characterization as somehow strange and aberrant, a fringe person, could not be further from the truth. In this homily, which matches up very comfortably with his other works, he is lending expression to the common faith of the Church, and he does so by 
drawing on traditions that antedate Christianity and extend back, through the New Testament writers, into the inheritance of biblical and immediately postbiblical Israel. He is entirely — or anyhow next to entirely — Semitic in his diction, and in fact very close indeed to the Rabbis with whom he quarrels.

In this latter respect, by bringing our attention back to the truth that our Lord insisted on to the Samaritan woman, that «Salvation is of the Jews», I think that Jacob can serve us today in a kind of double capacity. First of all, he should remind us that all that extraordinary panoply of polysyllabic Greek abstractions which we meet in the Greek Fathers, and which modern Orthodox theologians — God bless them! — are so anxious to invoke, often to the utter confusion or at least misperception of their Western Christian interlocutors, has its roots in, and was deployed in order to serve and protect, a fundamentally biblical and, yes, Jewish-based understanding of the redemption and salvation offered by Jesus Messiah. In short, Jacob and his fellow Syrians, from Aphrahat and Ephrem to Isaac of Nineveh — and even Dionysius the Areopagite, whom I have referred to a couple of times - help to demonstrate that our roots as Orthodox are planted firmly in the land of Israel.

This demonstration and reminder, secondly, should direct us - by whom I mean Orthodox believers in general and, specifically, those of us who claim to be doing Orthodox theology — to our biblical roots, which we will find readily enough to hand in the wealth of our liturgical texts which so often resonate to the same beat and almost as often to the very same imagery as moves Jacob, while much the same can be said of the literature of our spiritual writers. I should think that, for Orthodox in the United States, surrounded by a Protestant theological culture that insists on scriptural demonstration, such a biblical recourse would be obvious, but all too often it is not, and again all too often we find ourselves embarrassed by accusations that, for example, the doctrine of deification, or the teaching of the liturgy as in the likeness of heaven, or the emphasis on light and transfiguration, or the theology of the icon $^{66}$ are «Neoplatonist» in origin (an assertion that still serves,

${ }^{66}$ I would not deny the utility and importance of late Greek philosophy for the iconodules' defense of the images, but what often gets overlooked - aside, of course, from their obvious invocation of the Incarnation - is the resonance in their writings of very old, biblical themes around, exactly, the same notes of image/form and glory that we have been dealing with in this essay. Thus John of Damascus counters the very aniconic thrust of the Deuteronomist («You saw no form in the fire», Dt 4:12) with what is, effectively, an appeal to the Glory and image traditions of the Priestly source as they appear in Phil 2:6 ff. (and see above, nn. 21, 42, and 51-52). See B. Kotter (ed.), Die Schriften des Ioannes von Damaskos (Berlin, 1973) Vol. 3. 7883; ET: D. Anderson, St John of Damascus on the Divine Images (New York, 1980) 16-18. One might even read the eighth- and ninth-century debate as testifying to a certain continuity of tension in the «Israel of God», i.e., between the theologies of the «Name» and «Glory», and thus cf. LEVENSON's offhand remarks on this continuity, 
alas! as a kind of «default setting» in much too much contemporary analysis of patristic spirituality and mysticism), and we hasten to make clumsy apologies or, worse, indulge ourselves in a theology of reaction. Jacob, and the revolutionary developments in recent scholarship that have helped me present him in this essay, makes it very, very clear that we have no reason to apologize to our Protestant brethren, but rather that we are ourselves in a position, speaking from within Holy Tradition, to criticize and improve biblical scholarship itself. We have no need to fear, and every reason to speak and write boldly. This confidence in the Tradition as providing a true reading, as indeed the necessary starting-point and «place» for the reading of the scriptures and subsequent theology, is the point that the great twentieth-century advocates of patristic renewal, such as Fr. Georges Florovsky, or Vladimir Lossky, or the late Fr. John Meyendorff (to recall merely the theologians of the Russian emigration, especially the last, who was my own first and much-beloved instructor), were so anxious to press and apply. The tools available to us now, particularly for biblical studies and for the transition from the Second Temple to the New Testament and the Fathers, which is to say, for the very matrix of Christianity itself, are much better than those luminaries had available to them. Let Jacob and his fellows be a kind of summons to us to carry on the work, and to fill up the weaknesses (chiefly biblical), of that earlier generation.

By way of a last word, allow me to turn back to that matter of «mythology» that so troubled Professor Bondi. I argue that she got things wrong in Jacob because she depended on a now outdated scholarly construct, one which imported more into the ancients it sought to elucidate than it drew from them, and which in consequence obfuscated more than it illumined. There is still, however, the fact that Rudolf Bultmann, for example, availed himself of this

i.e., regarding Byzantine icons and temple traditions, in Sinai and Zion... 151. I cannot resist referring to a couple of passages I came across in reading the synaxarion for the Sunday of Orthodoxy. The voice of God comes to a revered ascetic and orders him to honor «the image of my form», and cf. thus the Empress Theodora's dream vision of the «man with a supernatural countenance» who speaks to her as God; in The Synaxarion of the Lenten Triodion and Pentecostarion / Eds. D. KIDD, G. URSACHE (Rives Junction, MI, 1999) 63-65. The Gospel pericope for the day, esp. Jn 1:51, also looks to ancient traditions around the Form and Glory. On the verse, see thus C. Rowland, John 1:51, Jewish Apocalyptic, and Targumic Traditions // NTS 30.3 (1984) 498-507, who argues that John is deploying a tradition attested in the Palestinian Targumim. The latter interpret the «descent» and «ascent» of the angels in Gen 28:12 as the heavenly beings first coming down to look at Jacob sleeping, then, on recognizing his face, going back to heaven to find his face, again, on the divine throne. Whether or not the first-century Evangelist knew this tradition, it seems clear to me that someone in mid-ninth century Constantinople knew of it, and so decided that this particular story was peculiarly apt for marking the restoration of, precisely, the veneration of the divine «Face». 
method in part — or mostly — because he sought ultimately to liberate the Christian Gospel, as he understood the latter, from what he deemed an impossibly archaic, mythical worldview, and that he believed he had found in Heideggerian existentialism the key to a preaching more relevant to «modern man». I admit that his concern is still relevant, at least in certain instances. I have merely argued that Jacob's «mythology» is no more nor less than traditional Christianity, and that he was not the least bit interested in translating those already age-old symbols and images into the abstractions of contemporary Greek philosophy. In his role as preacher, I think that he was largely correct, and I would further maintain that the old, essentially biblical language and imagery he deployed still work for congregations, are still powerful and moving exactly because they are so deeply grounded in the language of the revelation made once for all to Israel, and because they resonate in harmony with the Orthodox liturgy, including the latter's iconography, hymnography, and even the architecture of an Orthodox church - all of which, of course, are built on pretty much the very same foundations as Jacob's preaching. This is not to say, however, that there is no place for philosophical theology, but merely that the latter does not really belong in a sermon - unless the latter's hearers have very special needs, as can happen. In that respect, I think Bultmann's concern for «modern man» misplaced or, perhaps better, a bit confused. If by that phrase we mean «modernity», i.e., the philosophies and worldview of the Enlightenment and thereafter, then certainly there is a need for apologetics, and so for the exploitation of whatever resources are available to us in the realms of abstract thought. Here is the place for the recent arguments of, say, a Paul Valliere or a Fr. Michael Meerson, and their eloquent appeals to the wealth of Russian philosophical theology. ${ }^{67}$ If, on the other hand, we mean by «modern man» the contemporary believer, then I am less convinced of any pressing need to depart in basic ways from Jacob's idiom. He speaks essentially ad intra, within the Church, and it is her own cherished and aboriginal diction which he deploys. I would add that I think that his diction might well work for any Christian who is thoroughly versed in the Bible, such as many of our Protestant Evangelical compatriots. What it does not, cannot, and was never intended to do is to provide a ready-made entré into the universe of biblical (and so liturgical) symbols for the person who is completely unfamiliar with that world. For such a person catechetics, instruction, and, to be sure, apologetics are required. It is also true that many

${ }^{67}$ See P. Valliere, Modern Russian Theology: Bukharev, Soloviev, Bulgakov. Orthodox Theology in a New Key (Grand Rapids, 2000); M. MeErson, The Trinity of Love in Modern Russian Theology (Quincy, IL, 1998). The latter is very interesting in its account of the nineteenth and twentieth century, Russian appropriation of both Augustine's «psychological model» of the Trinity and of its expression in, especially, Richard of St Victor. 
of us who are believers also require, for ourselves, some philosophical rationale that engages the questions of the present age. Jacob, however, speaks wholly to and within the heart of the Christian mystery and the Church's life. This is at once his glory and his limitation. There is no need to slight the former when pointing out the latter. He has his place, and our brothers and sisters in the Syrian (Jacobite) Orthodox and Maronite Churches are right to celebrate him as, together with his beloved Ephrem, the great singer of the Faith.

\begin{abstract}
Jacob of Serug $(\dagger 521)$ is, after Ephrem of Nisibis, the most beloved of theologian poets among the Syriac-speaking Christians of the East. Until recently, though, he was not well known in Western Christian circles and, when discussed at all, was usually associated with Severus of Antioch and Philoxenus of Mabbug as part of a triad of the most important, early sixth-century «Monophysites» theologians. This article seeks rather to examine one of Jacob's works, the long verse homily on Ezekiel's chariot vision, against the background of those traditions common in particular to Eastern Christianity and looking to their origins in the Judaism of the Second Temple. The homily conjoins three biblical texts: Genesis 1:26; Ezekiel 1:26, 28; and Phillipians 2:6. Its point is simple and fully in accord with, especially, pre-Nicene Christianity: the one who appeared to Moses and the prophets is the same one who was born of Mary Theotokos. While making this point, however, Jacob draws on - and occasionally opposes and criticizes originally Second Temple Jewish traditions around the figure of Adam, mystical ascent to the divine throne, and the object of that ascent, the vision of the glorious form of God. He is thus a witness to the currency of these traditions in Christian circles, perhaps especially among the monks. His answer is the Eucharist. In the divine liturgy, he argues, everything that the prophet saw is present, and the one whom the ancients longed to go up to heaven to see, the one who rides on the throne of the cherubim, is present to the Christian in the bread and wine of communion.
\end{abstract}

